\title{
The impact of digital copyright law and policy on access to knowledge and learning
}

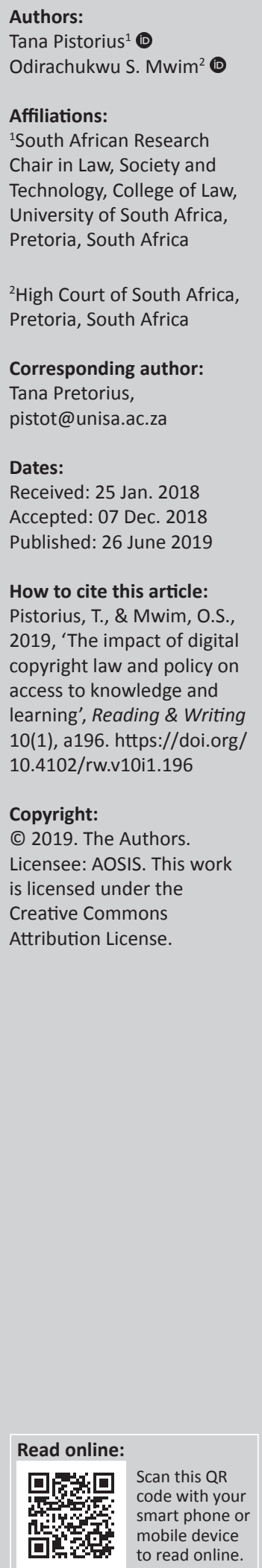

\section{Authors:}

Affiliations:

Technology, College of Law, University of South Africa,

${ }^{2} \mathrm{High}$ Court of South Africa, retoria, South Africa

Tana Pretorius,

ow to cite this article: 2019 'The impact of digital copyright law and policy on access to knowledge and 10(1), a196. https://doi.org/ 10.4102/rw.v10i1.196

Licensee: AOSIS. This work

is licensed under the

Creative Commons

Attribution License.
Background: The evolution in digital technologies has had an enormous impact on traditional copyright notions. Works in digital form have uniform characteristics and these works can be copied, distributed and stored with ease.

Objectives: The focus of this article was how to attain a balance between the need to promote access to works and therefore knowledge and learning, on the one hand, and the protection of the interests of copyright holders, on the other.

Method: Technological protection measures (TPMs) are applied to copyright works in digital form to curb infringement. The authors explore the extent to which TPMs impact on access the knowledge and learning.

Results: The findings of this article suggest a need for possible countermeasures in promoting knowledge and literacy through legislative reform that address the needs of creators and users in developing communities.

Conclusion: The authors conclude that TPMs may hinder data literacy, access to works, teaching and learning, particularly in developing communities. For example, recent attempts to revise South African copyright law have not attained a balanced approach.

Keywords: Digital; copyright; knowledge; development; legislation; technological protection measures; TPMs; copyright law; information; communication technologies; ICTs.

\section{Introduction}

Copyright law has always evolved in response to technological change. The need for copyright law arose with the invention of the printing press in the 15th century. According to Ploman and Hamilton (1980), printing privileges were granted in an attempt to regulate the printing of works. The first printing privilege was granted to Antonio Sabellico in 1486, followed by the privilege granted to the publisher Aldus Manutius in Venice in 1495 (Ploman \& Hamilton 1980). The revision of copyright law always follows the development of new technologies. A case in point is the legislative developments in response to the development of photography and computer technology (Lim 2007).

Digital technology is no exception. Digitisation challenges traditional concepts of copyright law such as the categorisation of works into different classes. Multimedia works defy classification. The seamless transmission of digital works and the ease with which works in digital form can be reproduced pose unheralded challenges to copyright law. Concerns regarding the impact of digitisation on copyright law led to the adoption by the World Intellectual Property Organisation (WIPO) of the WIPO Copyright Treaty (WCT) and the WIPO Performances and Phonograms Treaty (WPPT) in 1996. These treaties are commonly referred to as the 'Internet treaties'. Key traits of these treaties are the right of communication to the public, the making available right, the management of rights information and anti-circumvention provisions.

Technological protection measures (TPMs) are applied to copyright works in digital form to curb infringement. The circumvention of these TPMs is illegal. Books and other resources and learning go hand in hand. There is therefore an intimate relationship between copyright law and education. It therefore follows that any copyright provision that impedes access to copyright works will impede access to knowledge. This in turn will affect the knowledge divide.

\section{Research method}

This article examines the impact of copyright law and policy on access to digital content and therefore also access to knowledge and learning. It is assumed that the law should respond to

Note: This article is partially based on O.S. Mwim and T. Pistorius, 'Review of legal philosophical approach to digital copyright management and its implications for knowledge degeneration in Africa', 2017 Computing Conference, London, United Kingdom, July 18-20, 2017, pp. 1029-1034. https://doi.org/10.1109/SAl.2017.8252218 
technological change in a meaningful manner. It follows that, where copyright law evolves to address digital piracy, it is also assumed that the law should evolve in a manner that facilitates lawful uses. Copyright law serves both private and public interests. The private interest in copyright law is the author's exclusive rights to reap the fruits of their creative endeavours. The public interest in copyright law is the dissemination and use of works by the public. This article reviews the extent to which private rights in the digital sphere are balanced with public interests, in this case the right to have access to knowledge and learning materials.

In this article, an empirical-analytical approach was adopted through the review of the evolvement of copyright law to address the impact of digitisation. The analytical approach adopted in this article juxtaposes the traditional notions of copyright law and the management of the copyright protection of digital works. The interpretive approach was useful to illustrate the impact of information communication technologies (ICTs) on copyright regulation. Through the interpretative approach, the implications of court decisions and laws are also traced to access to knowledge. The approaches adopted in this article highlight the precarious line between the regulation of copyright and access to copyright works and therefore learning.

This article adopted an overall qualitative research approach in investigating the research problem. The research methodology involved a literature study of primary and secondary sources. This article traces the perspectives in two jurisdictions, namely the USA and South Africa, although other developments are also highlighted. The two jurisdictions were chosen because of the relevance of their copyright regimes to the research problem. The USA was included in this study as it is a developed country that has an advanced copyright regime. The USA follows a protectionist approach through which it protects its robust creative industries. South Africa is included in this study as it is a developing country. Although South Africa has wellestablished creative industries, it is a net importer of the USA's creative outputs. South Africa has several important national policy objectives, but relevant to this study is the recent emphasis on access to education. South Africa has also recently embarked on the revision of its copyright law. The proposed revision aims to address the impact of ICTs on South African copyright law as well as access to works.

\section{Schools of thought on copyright protection in the digital sphere}

Various schools of thought have addressed the challenges facing the copyright protection of works in digital form (Mwim \& Pistorius 2017:1029-1030). Legal scholars' philosophical approaches highlight the essential characteristics of the digital copyright paradigm. These schools of thought range from the complete abolishment of copyright protection of works to a moderate approach that embraces the public-private balance of rights. Extreme minimalists argue that copyright law is dead
(Lange 1992:139-151). This school of thought proposes the abolishment of copyright law for digital works as it is out of step with the current realities (Halstead 2002:195; Meeker 1993:195). The neo-classicists argue that the power currently in the hands of copyright owners should be tempered by public interests (Appel 1998:149, 1999:205-238). The postmodernists adopt a subjective view of digital copyright based on the collaborative notion of engaging with text (Appel 1999:205-238). Post-modernists were the trailblazers of the notion of user-generated works. Proponents of the moderate approach emphasise the importance of applying exceptions and limitations to copyright works in digital form (Netanel 1996:283-387).

We support a moderate approach, as it advocates a balanced approach. We think that a balanced and technologically neutral approach to copyright law is necessary. On the one hand, copyright law could become irrelevant and unworkable if inapposite copyright principles are applied to digital works. The converse is also true - copyright principles that have been developed to address digital issues are not applicable in the analogue world. A case in point is the temporary reproduction exception. Without this exception we would not be able to surf the Internet as a (temporary) copy is made when a person views a web page on a web browser. The temporary copy exception is vital to the digital world but completely inapplicable to traditional works.

\section{The USA}

\section{Introduction to the Digital Millennium Copyright Act}

The USA signed the WCT in 1996. In 1998, the USA adopted the Digital Millennium Copyright Act (WIPO Copyright and Performances and Phonograms Treaties Implementation Act of 1998 (17 USC § 101) (DMCA) to curb digital piracy (Loren 1999:835, 2002:133-148; Lunney 2001:813-920). The DMCA is consistent with the obligations created for member countries of the WCT.

The DMCA provides that copyright owners may apply TPMs to protect their copyright works from unauthorised copying and unauthorised access to the works. Copyright owners may also embed rights management information in their works to aid the management of their rights in the digital sphere. The 'anti-circumvention' provisions prohibit third parties from circumventing the TPMs and rights management information through the application of circumvention techniques and devices (17 USC $\S 1201$ of the DMCA).

Some authors (Appel 1999:155; Cho, Kim \& Shin 2015:9; Hettinger 1989:31) note that the DMCA prohibits both the use of decryption technologies (the act of circumvention) and access to decryption technologies (the trade in circumvention tools and technologies) (17 USC $\S 1201$ of the DMCA). The trade in circumvention tools and technologies is not objectionable if such tools or technologies have a commercial significance other than to circumvent (Iwahashi 2011:491). 


\section{Review of court decisions}

In a previous article, we traced the important cases that dealt with the copyright infringement under the DMCA (Mwim \& Pistorius 2017:1030-1035). Those cases are briefly referred to herein. Two important and more recent cases that deal with fair use and access to works are also discussed.

In the Sony Corp case (Sony Computer Entertainment America Inc $v$ Divineo Inc 457 F Supp 2d 957 [2006] 968), the court rejected a claim that the manufacturers of Sony video cassette recorders (VCRs) that could record television programmes should be liable for contributing to copyright infringement as the devices were incapable of non-infringing uses. This case established an important principle, namely that manufacturers of devices, such as VCRs, would not be liable for contributory infringement of copyright if the device in question was capable of substantial non-infringing uses. Lunney (2001:813-920) notes that the Sony Corp standard was applied in the Vault Corp v Quaid Software case (847 F 2d 255 [5th Circuit 1988]), where the court held that the decryption program developed by the defendant was capable of noninfringing uses because the program created proper archival copies. The making of archival copies was held to be substantially non-infringing.

The liability for trade in circumvention tools and technologies was addressed in the Universal City Studios v Reimerdes case (111 F Supp 2d 294 [SDNY 2000]). In this case, a group of young hackers based in Norway developed a program to circumvent the TPMs applied to films distributed on DVDs. (For a detailed discussion, see Beets 2001:793-834; Ku 2002:263-324; Yee et al. 2012:358-375). The circumvention program was made available for download, and it was posted on several sites dedicated to similar decryption activities. The court held that trafficking in a decryption program that enables unauthorised access to copyright works infringed the rights of the copyright owner (111 F Supp 2d 294 [SDNY 2000]).

In the Chamberlain case (Chamberlain Group Inc v Skylink Tech Inc 292 F Supp 44), the circumvention of a garage door opener was at issue. The defendant created a competing device that was programmed to function as a substitute garage door opener. The court rejected this action and held that the DMCA was only applicable to copyright works - the software embedded in the garage door opener was not copyrightable. Secondly, the court held that consumers had a basic right to use the embedded software they bought (Chamberlain Group Inc $v$ Skylink Tech, Inc 292 F Supp 44). It should be noted that copyright infringement cannot be justified by consumer demands. This sentiment was echoed in the UMG Recordings case (UMG Recordings Inc v MP3.com Inc [2000] 92 F Supp $2 \mathrm{~d} 349$ ). In this case, the court noted that the purpose of copyright protection was to protect the proprietary interests of copyright owners. Consumer demands or convenience fall outside the rationale for copyright and are not a justification for copyright infringement.
The Chamberlain ruling may seem to be at odds with previous decisions that held that circumvention infringes the DMCA. However, these cases dealt with the circumvention of copyright works, such as a computer program (video game player in the Sony Computer case) and an audiovisual work (the decryption of DVDs in the Universal City Studios v Reimerdes case and in 321 Studios v Metro Goldwyn Mayer Studios Inc 307 F Supp 2d 1085 [2004] 1103-05). Iwahashi (2011:491) has noted that the Chamberlain court applied the 'nexus test' to determine if a TPM is applied to a copyright work. The same test was applied in the MGE I case, where the court emphasised that TPMs must protect a copyright right, not some other right (MGE 1 No 08-10521 [2010] WL 2820006 at 3). In short, the DMCA is only applicable where the TPMs protect copyright works. Garage door openers and cartridges for printers (Lexmark Int'l Inc v Static Control Components Inc 387 F.3d 522 [2004] 546) fall outside this sphere.

The USA Copyright Act lists non-exhaustive factors that courts should consider in analysing claims of fair use, namely the purpose of the use; the nature of the work; the size and significance of the copied portion; and the effect of the use on the value or potential market for that work (17 U.S.C. $\S$ 107[1]-[4]). Two court cases that dealt with fair use of copyright works in the digital realm both touched on access to works, knowledge and learning. The one case dealt with the massive library of scanned books that Google created and the second case related to fair use in relation to electronic course packs.

In the Google Books case (Authors Guild v Google Inc No 13-4829 [2d Cir. 2015]), Google scanned millions of books into databases as part of its Library Project and its Google Books project. Authors of published books sued Google for copyright infringement. The district court held that the Google projects constituted fair use. The plaintiffs appealed to the Court of Appeals for the Second Circuit. They argued, amongst others, that Google's digital copying of full books created replacements of their books and that Google's repository of digital copies created a risk that these books would be downloaded by hackers and made freely available to users. The plaintiffs also argued that the fact that Google distributed the works to libraries would result in the eradication of their licensing income from libraries (Authors Guild v Google Inc No 13-4829 [2d Cir. 2015] at pp. 4-5).

The Court of Appeals rejected these arguments and concluded that the district court correctly sustained Google's fair use defence. The court held:

In sum, we conclude that: (1) Google's unauthorized digitizing of copyright-protected works, creation of a search functionality, and display of snippets from those works are non-infringing fair uses. The purpose of the copying is highly transformative, the public display of text is limited, and the revelations do not provide a significant market substitute for the protected aspects of the originals. Google's commercial nature and profit motivation do not justify denial of fair use. (2) Google's provision of digitized copies to the libraries that supplied the books, on the understanding that the libraries will use the copies in a manner consistent with 
the copyright law, also does not constitute infringement. Nor, on this record, is Google a contributory infringer.

In Cambridge University Press v Patton (Docket Number: 12-14676), three publishing houses sued Georgia State University (GSU) for copyright infringement. The case centred around GSU's electronic reserve system. Georgia State University professors routinely uploaded scans of chapters of books they wished to prescribe to students onto the GSU's electronic reserve system. The court referred to other 'coursepack cases' (such as Princeton University Press, 99 F.3d at 1389, and Basic Books, 758 F. Supp. at 1531-32) and noted that where the educational use in question was performed by a for-profit copy shop, it would be deemed to be commercial. The Supreme Court cautioned (p. 68) that although the teaching of university courses was clearly for educational purposes, the court held:

$[t]$ he crux of the profit/nonprofit distinction is not whether the sole motive of the use is monetary gain but whether the user stands to profit from exploitation of the copyrighted material without paying the customary price.

The court noted that the digital 'use' of a copyright work does not become 'fair use' just 'because the work is distributed via a hyperlink instead of a printing press' (at 120). The court held (at 115-116):

Checking the four statutory factors to ensure that they have been considered merely affirms the conclusion that what GSU is doing is not fair use.

This case does not involve an individual using a single copyrighted work, nor does it involve a single course, a single professor, or even a one-time use of 'multiple copies for classroom distribution'. See Campbell, supra, 510 U.S. at 579 n.11. Nor, in my opinion, should it be confined to the seventy-four specific instances of infringement that were the focus during trial. Rather, this case arises out of a university-wide practice to substitute 'paper coursepacks' (the functional equivalent of textbooks) that contained licensed copyrighted works with 'digital coursepacks' that contained unlicensed copyrighted works. This was done for the vast majority of courses offered at GSU and, as will be seen, it was done primarily to save money.

Although the court declined to expand the concept of 'transformativeness' to cover GSU's allegedly infringing use of portions of the plaintiffs' works, it held that GSU's failure to transform the underlying work was not critical if the use was for education. However, the Supreme Court held that the district court did err by giving each of the four fairuse factors equal weight and by treating the four factors mechanistically; the district court should have undertaken an all-inclusive review that cautiously weighted the four factors.

Importantly, the court also rejected the district court's reliance on the 'Classroom Guidelines' ('which dictate a ceiling of a 10 percent or one-chapter safe harbour') in its analysis of the individual instances of alleged infringement. The court said that each instance of alleged copying had to be considered individually, considering the quantity and the quality of the material (at page 91). The court noted that non-profit educational uses are more likely to be fair because they promote the ultimate aims of copyright - the creation and dissemination of knowledge. Both of these aims must be kept in mind when evaluating a claim of fair use (at page 108).

It is clear that the courts in the USA carefully balance the relevant factors in deciding fair-use cases. Furthermore, the copyrightability of the work protected by a TPM is paramount in cases dealing with the circumvention of TPMs. One should keep in mind that copyright law and policy of the USA have been carefully calibrated to enhance the growth of the USA's copyright industry.

We next examine South Africa's attempts at law reform, amongst others, to address the digital dilemma and also to introduce fair use.

\section{The legislative response in South Africa}

In 2013, the South African Government embarked upon a revision of South Africa's copyright law, the Copyright Act 98 of 1978. The Copyright Amendment Bill, 2015, was published for public comment in July 2015 (Government Notices 646 in Government Gazette No. 39028 [27 July 2015]). Subsequently the Copyright Amendment Bill, 2017, was published. The Copyright Amendment Bill of 2015 introduced the longawaited implementation of the WCT and the WPPT. The 2017 Amendment Bill builds on this first attempt to implement the Internet treaties in South African copyright law. It also deals with wide-sweeping amendments to South African copyright law by the proposed adoption of fair use as well as fairdealing provisions for educational activities. The latest version of the Copyright Amendment Bill (B 13B 2017) was published on 16 November 2018.

Some of the more controversial proposals that may lead to abuses include the provision that the reproduction of whole textbooks is permissible where the textbook is not for sale in South Africa or cannot be obtained at a price reasonably related to that normally charged in South Africa for comparable works. It is uncertain how the price for comparable works should be determined. Furthermore, educational institutions may incorporate copies of copyright works in:

printed and electronic course packs, study packs, resource lists and in any other material to be used in a course of instruction or in virtual learning environments, managed learning environments, virtual research environments or library environments hosted on a secure network and accessible only by the persons giving and receiving instruction at or from the educational establishment making such copies. (Clause 12D[2])

As noted infra, the last-mentioned were emphatically held to infringe copyright in the USA.

Provision is also made for placing works in open access repositories. The inspiration for the clause is article 38(4) of the German Copyright Act (Federal Law Gazette Part I, p. 3714, 
available at http://www.gesetze-im-internet.de/englisch_urhg/). Clause $12 \mathrm{D}(7)$ provides that:

(a) The author of a scientific or other contribution which is the result of a research activity that received at least 50 per cent of its funding from the state and which has appeared in a collection, has the right, despite granting the publisher or editor an exclusive right of use, to make the final manuscript version available to the public under an open licence or by means of an open access institutional repository.

(b) In the case of a contribution published in a collection that is issued periodically at least once per year, an agreement may provide for a delay in the exercise of this author's right referred to in paragraph (a) for up to 12 months from the date of first publication in that periodical. When the work is made available, the place of the first publication shall be properly acknowledged. Third parties, such as librarians, may carry out these activities on behalf of the author.

(e) Any agreement that denies the author any of the rights contemplated in this subsection shall be unenforceable.

Clause $28 \mathrm{P}(1)$ provides that notwithstanding the anticircumvention provisions in the Bill and in Section 86 of the Electronic Communications and Transactions Act 25 of 2002 (ECT Act), a person may use:

a technological protection measure circumvention device to perform:

(a) An act permitted in terms of any exception provided for in this Act.

(b) The sale, offer to sell, procurement for use, design, adaptation for use, distribution or possession of any device or data, including a computer program or a component, which is designed primarily to overcome security measures for the protection of data, in order to enable the performance of any act permitted in terms of paragraph (a).

Section $28 \mathrm{P}(1)$ (a) provides that any person may use a TPM circumvention device to perform an act permitted in terms of any exception provided for in the Copyright Act; or in terms of Section $28 \mathrm{P}(1)(\mathrm{b})$, the trade in circumvention devices in order to enable the performance of any permitted act.

It is submitted that the proposed permissible use of a TPM circumvention device is very wide. It is too wide. In this regard one may refer to the New Zealand Copyright Act, which provides in Section 226B that the rights that the issuer of a TPM work has under Section 226B do not prevent or restrict the making, importation, sale or letting for hire of a TPM circumvention device to enable a qualified person to exercise a permitted act using a circumvention device on behalf of the user of a TPM work. It is important to note that the permitted circumvention is limited to certain works by librarians or similar professionals. A similar approach is followed in Hong Kong (see Section 273(A)(8) of Chapter: 528 Copyright Ordinance).

Clause $28 \mathrm{O}(5)$ provides that a TPM shall be deemed to be effective where the use of the work is controlled by the exclusive licensee or copyright owner through the application of an access control or protection process, such as encryption, scrambling or other transformation of the work or a copy control mechanism that achieves the protection objective. Clause $28(\mathrm{O})(6)$ provides that the provisions must be read together with the provisions of sections 86,87 and 88 of the ECT Act. These provisions form part of the cybercrime provisions.

Section 86 of the ECT Act relates to the unauthorised access to, interception of or interference with data and is in essence an anti-circumvention prohibition (Pistorius 2006:6-7). The ECT Act prohibits the production, distribution and use of devices and applications designed primarily for the purpose of overcoming data-protection security measures. The criminalisation of the circumvention of TPMs may soon become a moot point as the Cybercrimes Bill, 2017 (B6B-2017), provides for the deletion of sections 86, 87 and 88 of the ECT Act (clause 58 and the Schedule to the Cybercrimes Bill).

\section{Possible implications for developing countries}

Several African countries have deposited their instruments of ratification or accession to the WCT. These include Algeria, Botswana, Burkina Faso, Burundi, Ghana, Gabon, Guinea, Madagascar, Mali, Moroko, Nigeria, Senegal and Togo (see http:/ / www.wipo.int/treaties/en/ShowResults.jsp?lang= en\&treaty_id=16).

A developmental approach to copyright protection is necessary in developing countries in order to address several important policy objectives. In this regard, Nwauche (2005a:377) has noted:

The appropriate response of developing countries, including African countries to the WIPO digital treaties has attracted the attention of individuals and groups alike. The fact that there is no agreed consensus on the expression of exceptions and limitations at the international level under the Berne framework and under the WIPO digital treaties underscores the point that they ought to be created in response to the circumstances of each nation. A national response expresses the needs and aspirations of each country. An analysis of the human rights obligations of African countries must have a significant impact on these exceptions and limitations.

The African countries listed above have not attained a balance in their laws on the 'legal protection of technological protection measures and effective legal remedies against the circumvention' of such measures as opposed to the right of users to access the works protected by the TPMs (Nwauche 2005b). In this regard, the provisions in the South African Copyright Amendment Bill, 2017, overreaches to address user rights.

South Africa has adopted an ill-advised and radical approach to address this conundrum in its recent proposals to amend the Copyright Act. The approach adopted in South Africa is in stark contrast to the position held in the USA. As noted previously, in the UMG Recordings Inc case (UMG Recordings Inc v MP3.com Inc [2000] 92 F Supp 2d 349), the court noted that copyright is not designed to afford consumer protection 
or convenience but rather to protect the copyright holder's property interests.

The proposed amendments through which South Africa has attempted to address TPMs and the right to access works are radical and in some instances unworkable. Expansive rights that go beyond the right to deal fairly with a work are proposed for users. One might argue that this approach is justified in light of the educational needs of South Africa. However, it is submitted that it is also as important to protect South Africa's vulnerable cultural industries.

\section{Conclusion}

Copyright protection is not absolute, and copyright law makes provision for exceptions and limitations. It is generally recognised that users have a legitimate interest in being able to use a copyright work without the permission of its copyright owner. Fair dealing in general allows a copyright user to reproduce a work for the purposes of private study. As noted above, the use of TPMs can completely negate the fair dealing provisions. If a TPM prevents a user from accessing a work, it then also overrides any fair dealing right the user has. The net effect of technological locks on education and learning is immense.

As noted above by Nwauche (2005a:377), exceptions and limitations ought to be created by developing countries to address the circumstances of each nation. As noted infra, the recent emphasis on access to affordable education in South Africa has come to the fore. We question to what extent the approaches adopted by the South African legislature is geared towards free access to copyright works to the demise of the fundamental objective of copyright protection: to balance public and private rights.

It is suggested that developing countries' rationale for copyright protection should be adapted in accordance with their economic and social realities. The South African legislature should adopt tempered exception and limitations to the use of TPMs, based on sound policy objectives. The approach adopted in the Copyright Amendment Bill favours a radical approach. A tempered approach that provides for regulated access to circumvention for fair use or fair dealing purposes, as is provided for in New Zealand, is preferable. The current wording of the Copyright Amendment Bill is out of step with South Africa's international obligations in terms of the WCT and the WPPT. Secondly, it could lead to abuses. For example, a user may download or copy an electronic textbook published in Europe where the textbook is not available for sale in South Africa through the application of a TPM circumvention device. This could lead to the geoblocking of electronic resources. Geoblocking will adversely impact on access to knowledge and learning. Thirdly, the proposed copyright reform will deter knowledge generation. South African academics will publish less as the market that currently exists for academic works will no longer exist if the Copyright Bill is enacted. Academic authors will also increasingly publish in overseas journals. This will lead to knowledge degeneration and will have a direct and negative impact on access to knowledge and learning.
Possible future research in the area of digital copyright and access to knowledge would be to measure in quantifiable terms, the impact of copyright law and policy on the generation of knowledge. Secondly, examining the individual communities in Africa and proposing frameworks that could be adopted in such communities to address their challenges will be valuable.

\section{Acknowledgements}

This work is based on the research supported by the South African Research Chairs Initiative of the Department of Science and Technology and National Research Foundation of South Africa (Grant No 98405).

\section{Competing interests}

The authors declare that they have no financial or personal relationships that may have inappropriately influenced them in writing this article.

\section{Authors' contribution}

T.P. is O.S.M.'s supervisor. The first part of the article is based on research the latter did for his Master of Laws (LLM) degree. T.P. wrote the introduction and the last part of the analysis of case law in the United States and legislative developments in South Africa. Both T.P. and O.S.M. contributed to the conclusions.

\section{References}

321 Studios v Metro Goldwyn Mayer Studios Inc 307 F Supp 2d 1085, (2004) 1103-05. Appel, S., 1998, 'Copyright, digitization of images, and art museums: Cyberspace and other new frontiers', UCLA Entertainment Law Review 6, 149.

Appel, S.E., 1999, 'The copyright wars at the digital frontier: Which side are art museums on?', The Journal of Arts Management, Law, and Society 29(3) 205-238. https://doi.org/10.1080/10632929909597303

Authors Guild v Google Inc No 13-4829 (2d Cir. 2015).

Bagchi, K., 2014, 'Factors contributing to global digital divide: Some empirical results', Journal of Global Information Technology Management 8(3), 47-65. https://doi. org/10.1080/1097198X.2005.10856402

Beets, R.P., 2001, 'Articles from law reviews and copyright periodicals', Kentucky Law Journal 89(3), 793-834.

Blakeney, M. \& Mengistie, G., 2011, 'Intellectual property and economic development in sub-Saharan Africa', The Journal of World Intellectual Property 14(3-4) 238-264. https://doi.org/10.1111/j.1747-1796.2011.00417.x

Cambridge University Press v Patton (Docket Number: 12-14676) 769 F.3d 1232 (11th Cir. 2014).

Chamberlain Group Inc v Skylink Techs Inc 292 F Supp. 2d 1040, viewed n.d., from https://www.courtlistener.com/opinion/2331814/chamberlain-group-inc-v-skylinktechnologies/.

Cho, K., Kim, C. \& Shin, J., 2015, 'Differential effects of intellectual property rights on innovation and economic performance: A cross-industry investigation', Science and Public Policy 42(6):827-840.

Chowbe, V.S., 2010, 'Intellectual property and its protection in cyberspace', IUP Journal of Intellectual Property Rights 9(1\&2), 7-41.

Dreier, 1995, 'Unsolved copyright issues in digital and network environment', Copyright World 36.

Halstead, F.M., 2002, 'Regulated become the regulators problems and pitfalls in the new world of digital copyright legislation', Tulsa Law Review 38, 195.

Hettinger, E.C., 1989, 'Justifying intellectual property', Philosophy \& Public Affairs 18(1), 31.

IMS Inquiry Management Systems Ltd v Berkshire Information Systems Inc 307 F Supp 2d 521 (2004) 523

Iwahashi, R., 2011, 'How to circumvent technological protection measures without violating the DMCA: An examination of technological protection measures under current legal standards', Berkeley Technology Law Journal 26, 491. 
Ku, R.S.R., 2002, 'The creative destruction of copyright: Napster and the new economics of digital technology', The University of Chicago Law Review 69(1), 263-324. https://doi.org/10.2307/1600355

Lange, D., 1992, 'At play in the fields of the word: Copyright and the construction of authorship in the post-literate millennium', Law and Contemporary Problem 55(2), 139-151. https://doi.org/10.2307/1191779

Lexmark Int'l Inc v Static Control Components Inc 387 F.3d 522 (2004) 546.

Lim, Y.F., 2007, Cyberspace law commentaries and materials, 2nd edn., Oxford University Press, London.

Loren, L.P., 1999, 'Digitization, commodification, criminalization: The evolution of criminal copyright infringement and the importance of the willfulness requirement' Washington University Law Quarterly 77, 835.

Loren, L.P., 2002, 'Technological protections in copyright law: Is more legal protection needed?' International Review of Law, Computers \& Technology 16(2), 133-148. needed?' International Review of Law, Computers
https://doi.org/10.1080/1360086022000003964

Lunney, G.S., Jr., 2001, 'The death of copyright: Digital technology, private copying, and the Digital Millennium Copyright Act', Virginia Law Review 813-920. https:// doi.org/10.2307/1073857

Matz, R.C., 2000, 'Bridgeman art library, Ltd. v. Corel Corp', Berkeley Technology Law Journal 15(1), 3-23.

Meeker, H.J., 1993, 'Ineluctable modality of the visible: Fair use and fine arts in the post-modern era', University of Miami Entertainment \& Sports Law Review $10,195$.

MGE 1 No 08-10521 (2010) WL 2820006

Mwim, O.S. \& Pistorius, T., 2017, 'Review of legal philosophical approach to digital copyright management and its implications for knowledge degeneration in Africa',
in 2017 Computing Conference, London, United Kingdom, pp. 1029-1034. https:// in 2017 .org/10.1109/SAl.2017.8252076
Netanel, N.W., 1996, 'Copyright and a democratic civil society', Yale Law Journal 106(2), 283-387. https://doi.org/10.2307/797212

Nwauche, E.S., 2005a, 'African countries access to knowledge and the WIPO digital treaties', The Journal of World Intellectual Property 361(8), 377. https://doi. org/10.1111/j.1747-1796.2005.tb00254.x

Nwauche, E.S., 2005b, 'A development oriented intellectual property regime for Africa', paper presented at the 11th General Assembly of the Council for the Development of Social Science Research for Africa (CODESRIA), Maputo, Mozambique, 6-10 December, 2005.

Pearl Inv LLC v Standard I/O Inc 257 F Supp 2d 326 (2003), 349-350.

Pistorius, T., 2006, 'Developing countries and copyright in the information age', Potchefstroom Electronic Law Journal 2, 6-7.

Ploman, E.W. \& L.C. Hamilton, 1980, Copyright intellectual property in the information age, Routledge \& Kegan Paul, Boston, MA.

Sony Computer Entm't Am Inc v Divineo Inc 457 F Supp 2d 957 (2006) 968.

Sony Corp of America $v$ Universal City Studios 464 US (1984).

Ticketmaster LLC v RMG Techs Inc 507 F. Supp 2d 1096 (2007), 1111-1113.

UMG Recordings Inc v MP3.com Inc (2000) 92FSupp 2d 349.

Universal City Studios v Reimerdes 111F Supp 2d 294ff (SDNY2000).

Vault Corp v Quaid Software 847 F 2d 255 (5th Circuit 1988).

World Intellectual Property Organization (WIPO) Copyright and Performances and Phonograms Treaties Implementation Act of 1998 (17 USC 101).

Yee, K.K., Keun, L., Walter, G.P. \& Kineung, C., 2012, 'Appropriate intellectual property protection and economic growth in countries at different levels of property protection and economic growth in countries at different levels of
development', Research Policy 41, 358-375. https://doi.org/10.1016/j.respol. 2011.09.003 